\title{
Cambodia's Garment Industry and Labor Conditions - A Showcase for Social Sustainability, or not better than its Neighbors?
}

\author{
By Nathalie Homlong* \\ Elisabeth Springler"
}

The garment industry accounts for a lion's share of Cambodia's exports, and about a quarter of industrial employment in the country. An agreement with the USA on preferential trade terms based on the stipulation of better working conditions led to an improvement of working conditions in Cambodia's garment industry. This also has had a positive effect on demand for garments produced in Cambodia, as good working conditions are increasingly important for clothing brands. In the last years, however, after the end of a trade agreement with the USA, the industry has been increasingly experiencing strikes and labor unrest, as well as a decline in demand. Also, China (a major investor in this industry) has partly moved production to cheaper locations. This leads to the following research questions/starting points:

- Assessment of the labor conditions in the garment industry in Cambodia.

- What are the potentials and challenges for sustainable social development in Cambodia's textile industry?

The paper combines qualitative and quantitative research methods by integrating a SWOT analysis and analysis of statistical data to show the tensions between economic development and social cohesion in this emerging economy.

\section{Introduction}

Economic development in less developed economies and emerging markets in Asia focused in the past decades mostly on export driven economic growth (Oately 2010). This trend is also observable in Cambodia (Ravin and Cheong 2013), starting first in the 1970s and then again in the 1990s after the end of the Khmer Rouge regime, with numerous structural reforms towards becoming a market economy. This strategy was especially pursued in the decade before the global financial crisis, when Cambodia experienced economic growth rates of around $10 \%$. Negative effects of such an approach of economic development cumulated in the past in economic downturns and recessions, after supply chains shifted towards other export-oriented economies. Therefore, export-oriented economies, which lack internal demand to compensate for diminishing external demand in the case that supply chains are shifted, tend to cut on monetary and social compensation for workers, or

\footnotetext{
* Professor, Volda University College, Norway.

${ }^{\dagger}$ Professor, Program Director European Economy and Business Management, UAS bfi Vienna, Austria.
} 
even disobey fundamental regulations against child labor to keep up the economic position in the global production network. Consequently, trade liberalization policies, which are favored in less developed economies to promote the national export sector, might be seen as stumbling blocks against sustainable social development. Such policies being implemented at the lowskilled-labour-intensive apparel sector characterized by low-entry barriers could lead to an increasing probability of strike from the workers' side, loss in firms' productivity and reallocation of the companies to competitor countries offering more favorable production conditions (Staritz 2012).

In the case of Cambodia, this specific sector has been one of the driving forces of economic growth. As it is estimated that the garment industry comprises about 500,000 employees and 500 factories (Better Work 2014), this sector is of significant importance for the country's overall economic development. Facing these developments, Cambodia's authorities introduced in the past years changes in the legal settings as well as institutional reforms to improve labor conditions. This should enable the economy to follow a structured approach of economic development that allows for sustainable social and economic development-following among others the examples of Taiwan and South Korea in applying the so-called East Asian Model of Development (Oately 2010).

Therefore, this paper analyzes the recent structural and institutional reforms in the garment sector aiming at social sustainable development and good working conditions and assesses in the following the strengths and weaknesses of the Cambodian garment industry in a SWOT analysis.

\section{Setting the Theoretical Scene in Cambodia's Developing Economic Environment: On the Importance of the Labor Market for Sustainable Development}

The garment industry, as well as tourism, construction, and agriculture, are major drivers for economic growth in Cambodia (Central Intelligence Agency 2013). In spite of strong economic growth rates before the global economic crisis and a recovery of GDP growth following the crisis (coming to $7.0 \%$ in 2014, Asian Development Bank 2015), GDP per capita is still below the average among developing Asian nations. Since 1990, the gap between GDP per capita in purchasing power parities between Cambodia and other developing Asian nations has even continuously widened (World Economic Forum 2013). In the years before the global economic crisis, a concentration of wealth in the hands of the richest $10 \%$ of the population could be observed. Also wage inequalities are pronounced, but the gap in earnings between workers with high and low wages has become smaller in recent years. (International Labor Office 2012)

The period of rising growth rates that Cambodia has been through is not a unique phenomenon for developing countries. Numerous Asian economies, e.g. 
China, Taiwan and Singapore experienced high economic development over the last decades and managed to achieve a sustainable development path.

Nevertheless, many other economies of the region are constantly lagging behind and serve as suppliers for low technology products. While standard economic approaches, e.g. studies in line of tradition of Heckscher-OhlinSamuelson (Leamer 1995), suggest that export strategies of less developed economies in combination with liberal trade policies lead to economic growth and further on also to a convergence of prices for production factors, alternative approaches show that such strategies might only lead to short-term economic growth. Following the Singer-Prebish hypothesis, especially the export of low technology products and agricultural products do not lead to sustainable growth, but due to low income elasticity of these products only to short-term economic development (Oately 2010). Income increases in importing economies lead to an erosion of exports for less developed economies. Therefore, it is imperative that the production sectors of less developed economies do not concentrate on the exploitation of cheap and unskilled labor, but aim to promote active industrial policies in combination with exports.

Following Myrdal (1973), who has shown the negative effects of rapid industrialization in Asian Economies, these policies have to consider both the structural background of these economies and the potential for development of small and medium sized enterprises in these nations. Additionally, improvements in education promote economic progress. Regardless the fact that Gunnar Myrdal's analysis focuses on the Asian situation in the decades after the Second World War, the theoretical discussion of how to overcome economic underdevelopment is unchanged. While analysis in the line of neoclassical economies claims that the economic development process has to aim at the supply side and that the labor market should impose as flexible wages as possible to respond to the business cycle, alternative approaches focus on the importance of the institutional and structural settings of the respective economies, and have a more differentiated view of the labor market, following a segmented market theory.

Given the empirical evidences of the Cambodian economy discussed above, the latter approach seems to be better suited to promote sustainable development of the economy.

Segmented Production Sectors and Labor Demand Inter-linkages between Labor Demand and Economic Development

Unlike standard economic approaches, which mainly assume full competition in their understanding of production sectors, alternatives assume that sub-sectors of the production sector show different competitive structures. Differences in the competitive environment are especially visible when clustering production sub-sectors according to their level of capital and technology use in production (Appelbaum 1979, Seccareccia 1991). While higher production-subsectors, which use higher levels of technology, are 
situated in a less competitive environment, sectors with lower capital to labor ratios are more competitive. Additionally, these sectors are also characterized by lower skilled labor and lower wage levels. Consequently, production sectors with higher technology ratios and higher skilled labor forces also invest in the further education of their employees and show a more stable demand for labor, compared to companies with lower capital to labor ratios. This leads also to segmentation within the labor market, into a so-called primary and secondary market (Appelbaum 1979). Therefore, the labor market does not lead to equilibrium between supply and demand independently from the production sector, but depends on the structural features of the goods market (King 2001).

\section{Linkages between the Labor Market Structure and Economic Development}

Given the facts discussed in the previous section, two implications for the promotion of economic development can be derived: Firstly, it means that a lack in higher technology sectors also hinders national macroeconomic demand and increases the dependence on an emerging market of exports. Secondly, the segmentation of the labor market also promotes increasing income inequality between employees (King 2001), and hinders the establishment of a so-called middle class (Appelbaum 1985). The relative wage increase of rather small elite of employees in the higher technology sectors diminishes also overall national consumption, compared to a situation of more equal wages. Promoting, national consumption, which in turn should enable to fulfill the transition from a less developed economy towards a higher developed economy as it was shown, for example by the adjusted structural approaches of Japan (Oatlely 2010), which focused on a strong educational element, mainly these economic policies are demanded (King 2001) by enforceable worker rights as elements of the re-regulation of the labor market, wage-fixing institutions to establish and maintain the real value of minimum wages, and public sector intervention on the labor market especially for those who are unemployed.

As the focus of this paper, is the potential of the garment industry in Cambodia for sustainable economic and social development, unemployment is only touched marginally. Therefore, the potential of the sector to promote sustainable economic development will be measured by its capability to promote national consumption. This in turn should enable capital accumulation and promote innovation in other sectors of the economy.

Following from this, especially the demanded economic policies regarding the level and enforcements of labor rights and working conditions and the institutional structure of the wage bargaining process shall be analyzed.

\section{Cambodia's Garment Industry}

In this section first the significance of the garment industry for Cambodia's economy is highlighted. This is followed by an analysis of the institutional settings, relevant international agreements, and labor conditions in 
the garment industry, which serve as the basis for an analysis of strengths and weaknesses of this sector in the following section.

\section{Importance for the Economy and International Agreements}

The Cambodian garment industry was established rather recently, in 1994, with the help of foreign direct investments. The Cambodian government followed a policy aiming at actively attracting foreign investors with generous incentives (Source ASEAN 2010). Approximately 15\% of Cambodia's GDP (Asuyama and Neou 2012) and about $80 \%$ of the country's total export revenue (Better Factories) are generated by the garment industry. Cambodia is among the leading exporting nations of garments, however the share on the world market does not account for more than $1 \%{ }^{1}$.

An important milestone for Cambodia's garment industry was the Bilateral Textile Agreement with the United States. The agreement, which was signed in 1999 and was in force until 2005, was the only USA bilateral labor agreement that linked increased market access to improved compliance with labor regulations. Standards included among others payment of minimum wages, limiting hours of work, prohibition of child labor and forced labor, and freedom of association (Wells 2006). This led to Cambodia developing a reputation as a labor-friendly producer of garments, which in turn helped increase employment and exports.

Today the "Everything but Arms" initiative by the EU for LDCs is a major driver for Cambodia's garment exports to the European Union (Phnom Penh Securities 2012). This is also reflected in strong increases of garment exports from Cambodia to the EU. These reached USD 400 million in the first quarter of 2014 , that is an increase by $24 \%$ compared to the same period in 2013 . In the first quarter of 2014 garments worth USD 462 million were exported to the USA - a decrease by $11 \%$ compared to the first quarter of 2013 (GMAC 2014).

\section{Institutional Settings}

Workers' rights and labor conditions are set in the Labor Code of 1997 and the eight core labor conventions of the ILO were signed in 1999 (National Institute of Statistics 2010). The Labor Code gave the Ministry of Labor the authority to set minimum wages. So far the garment, textile and footware industry is the only industries were minimum wages have been set (Cambodia Institute of Development Study 2009). The establishment of trade unions and the process of collective bargaining in the garment industry emerged primarily after 2004. In the year 2004 first collective bargaining agreements were reached in the hotel industry (National Institute of Statistics 2010). For the garment industry, the government supported the establishment of the federation of employers, the Garment Manufacturers Association of Cambodia (GMAC), which as the oldest employers' association was established in 1996 (ACTIF 2010). In industrial relations 28 federations of trade unions represent workers

\footnotetext{
${ }^{1}$ Figure for 2011; Table II.69 (WTO 2013).
} 
in the garment sector and interact with the employers' associations in the garment industry, which are members in the umbrella organization The Cambodian Federation of Employers and Business Associations (National Institute of Statistics 2010).

As Figure 1 shows, unionization rates in the garment industry increased after the global financial crisis from $43 \%$ to $58 \%$, indicating the workers' overall willingness to engage in the bargaining processes and in improving working conditions. Similarly, numerous garment factories reported to have at least one workers' union in their company. Nevertheless, the social pressure on workers is apparent when looking at the percentage of companies admitting to violating the workers' rights to forming an association. Data seems to reflect the dual picture of the current situation in the Cambodian garment industry. While a majority of companies aims at observing labor standards, the situation is getting worse for workers in a minority of companies, where not even fundamental rights are adhered to.

Figure 1. Union Density and Freedom of Association 2008-2013

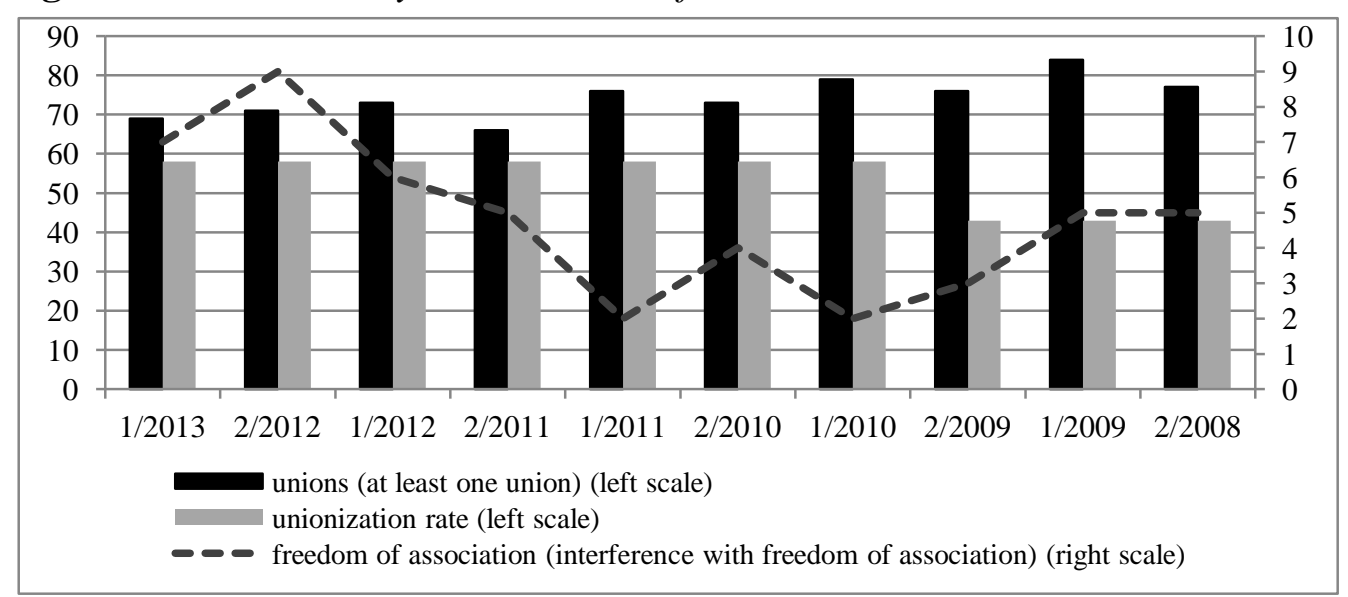

Source: Better Factories (various years).

A Memorandum of Understanding was signed between GMAC and six (now eight) major trade union federations and renewed in 2012 to comply with the existing labor dispute resolution mechanism, which states that the right to strike is guaranteed after the labor dispute resolution procedure is exhausted (GMAC 2013). In spite of that, the number of strikes is increasing. During the global financial crisis a decrease in the overall number of strikes could be observed (from 105 in 2008 to 34 in 2011). As Figure 2 shows, the number of strikes increased in 2012 by more than $250 \%$ to 121 strikes. Lost man-days in this period cumulated to more than 540,000 (GMAC 2013). A major reason for the ongoing labor disputes is the demand to increase minimum wages in the garment industry. 
Figure 2. Number of Strikes and Percentage Change 2003-2013

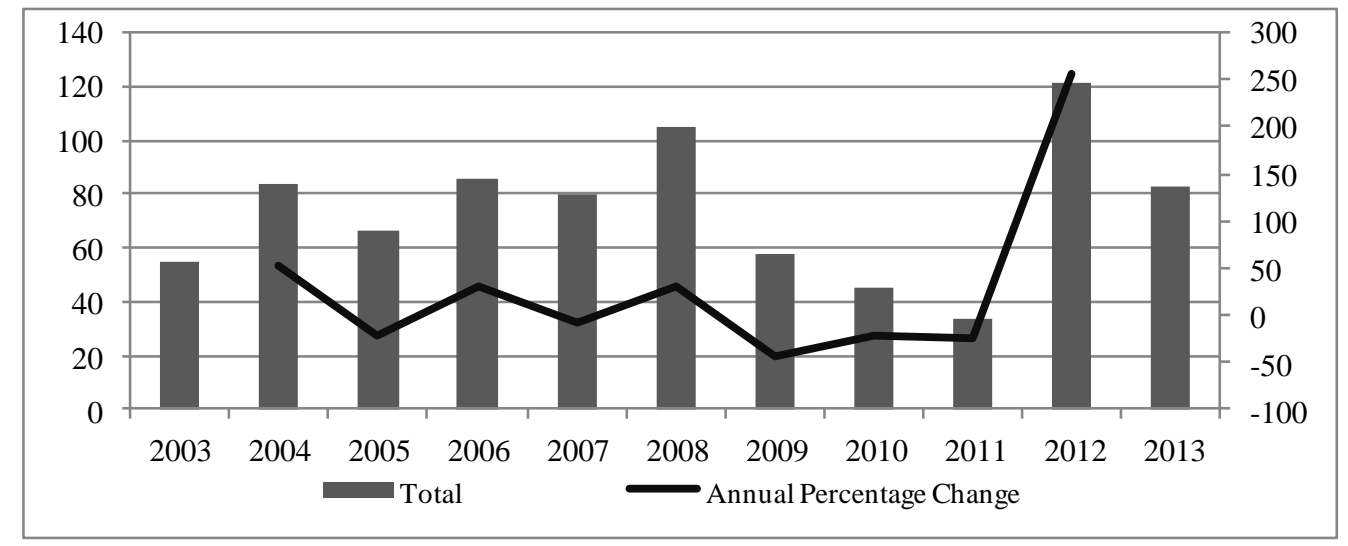

Source: GMAC website.

\section{Socio-economic Characteristics of the Workers}

With $83 \%$ (Figure for 2009), the workforce in this industry consists predominantly of female workers (Savchenko and Acevedo 2012). About 85 to $90 \%$ of the workers originate from rural regions and migrated to more central areas, where production sites are located. Earnings sent by workers to their families residing in peripheral areas are also a major economic factor for the rural areas of origin of these workers (Arnold 2013). Female garment workers have on average 6.5 years of schooling, slightly more than the average of 6 years of schooling for the rest of the female labor force (Savchenko and Acevedo 2012).

\section{Labor Conditions, Monitoring and Compliance with Regulations}

Fires and the collapse of a building in textile and garment factories in Bangladesh in 2012 and 2013 have called international attention to working conditions in textile and garment factories in developing countries. The discussion of working conditions raises the question of how "good" working conditions can be defined. As Table 1 shown, working conditions comprise a multitude of dimensions and indicators, and with several of these indicators the minimum standards can be subject to discussion. The International Labor Organization launched an approached called "Decent Work", which is defined as "productive work for women and men in conditions of freedom, equity, security and human dignity" (Öz 2008). Decent Work includes also dimensions which are related to the overall living conditions of the workers, and which go beyond the working conditions at the workplace, like combining work and family. In contrast to the ILO's approach, this paper intends to analyze changes in actual working conditions. Therefore, the focus is put on wage, leave/holiday and contract related indicators, as it can be assumed that these are the areas in which employers will see the greatest incentive in discontinuing high work standards after the end of the Bilateral Textile Agreement, since these standards would have the highest potential for savings 
in employee related costs. Since a worsening in these conditions can be expected to result in increased actions by unions, the status of freedom of association discussed in the relevant section pertaining to the institutional environment of the market is a significant determinant of the level to which the garment industry complies with the legislation.

Table 1. Working Conditions

\begin{tabular}{|c|c|}
\hline Category & Indicators \\
\hline \multirow{3}{*}{ Remuneration } & Wage per hour \\
\hline & Minimum payment requirements not observed/observed/exceeded \\
\hline & Overtime payment \\
\hline \multirow{3}{*}{$\begin{array}{l}\text { Additional } \\
\text { benefits }\end{array}$} & Paid sickleave \\
\hline & Maternity leave \\
\hline & Health insurance \\
\hline \multirow{6}{*}{$\begin{array}{l}\text { Physical work } \\
\text { environment }\end{array}$} & Equipment \\
\hline & Lighting \\
\hline & Temperature \\
\hline & Ventilation \\
\hline & Emergency exits \\
\hline & Emergency routines \\
\hline \multirow{6}{*}{$\begin{array}{l}\text { Work time } \\
\text { and time off }\end{array}$} & Daily / weekly / monthly work hours \\
\hline & Overtime per day / week / month \\
\hline & Night work \\
\hline & Breaks \\
\hline & Number of holidays \\
\hline & Number of sickdays \\
\hline \multirow{3}{*}{ Health } & Exposure to harmful substances, noise, risky work settings \\
\hline & Accidents \\
\hline & Health services \\
\hline Work contract & Permanent/temporary/no contract \\
\hline \multirow{4}{*}{ Other } & Unionization permitted \\
\hline & Child labor \\
\hline & Forced work \\
\hline & Discrimination \\
\hline
\end{tabular}

Source: Own presentation.

Figure 3 shows the compliance with regulations by factories that are monitored by the Better Factory initiative. This initiative is run by the International Labor Organization and is supported by the government, trade unions, as well as the industry employers' association. Monitoring whether working conditions in the garment industry are in line with national and international labor standards is at the core of Better Factories' activities (Better Factories various years). In the time period 2008 to 2013 especially the share of companies paying for maternity leaves fluctuated strongly, with particularly low compliance rates in 2010. On the other hand, payments of minimum wages for regular and piece-rate workers show a steady high adherence rate, while it seems that rather payments to casual workers are used by employers to cut labor related costs during periods of economic downturn. When it comes to 
hourly wage levels for garment workers in Cambodia, these are with USD 0.33 per hour among the lowest compared to the country's main regional competitors in East and South East Asia (Staritz 2011: Table 4.13). In this context a comparison of wages in the garment industry compared to other professions in Cambodia is also of interest. In an interview conducted in 2010, a representative of a company that monitors working conditions in the garment industry in Cambodia commented that the wage levels in the garment industry in Cambodia were still clearly above those of other professions. While the minimum wage for the garment industry was at USD 61, the minimum wage for example for police was only USD 25 at that time (interview Gridling, 2010). In general, casual workers make up a significant share of the work force in the monitored garment factories. Another important aspect in the contractual framework is the fact that only a minority of workers, who are employed in a garment factory over two years, also have a contract of a year or longer. More than $40 \%$ of workers, who work for one company for more than two years, do not even have a formal work contract.

Figure 3. Labor Conditions-Payments

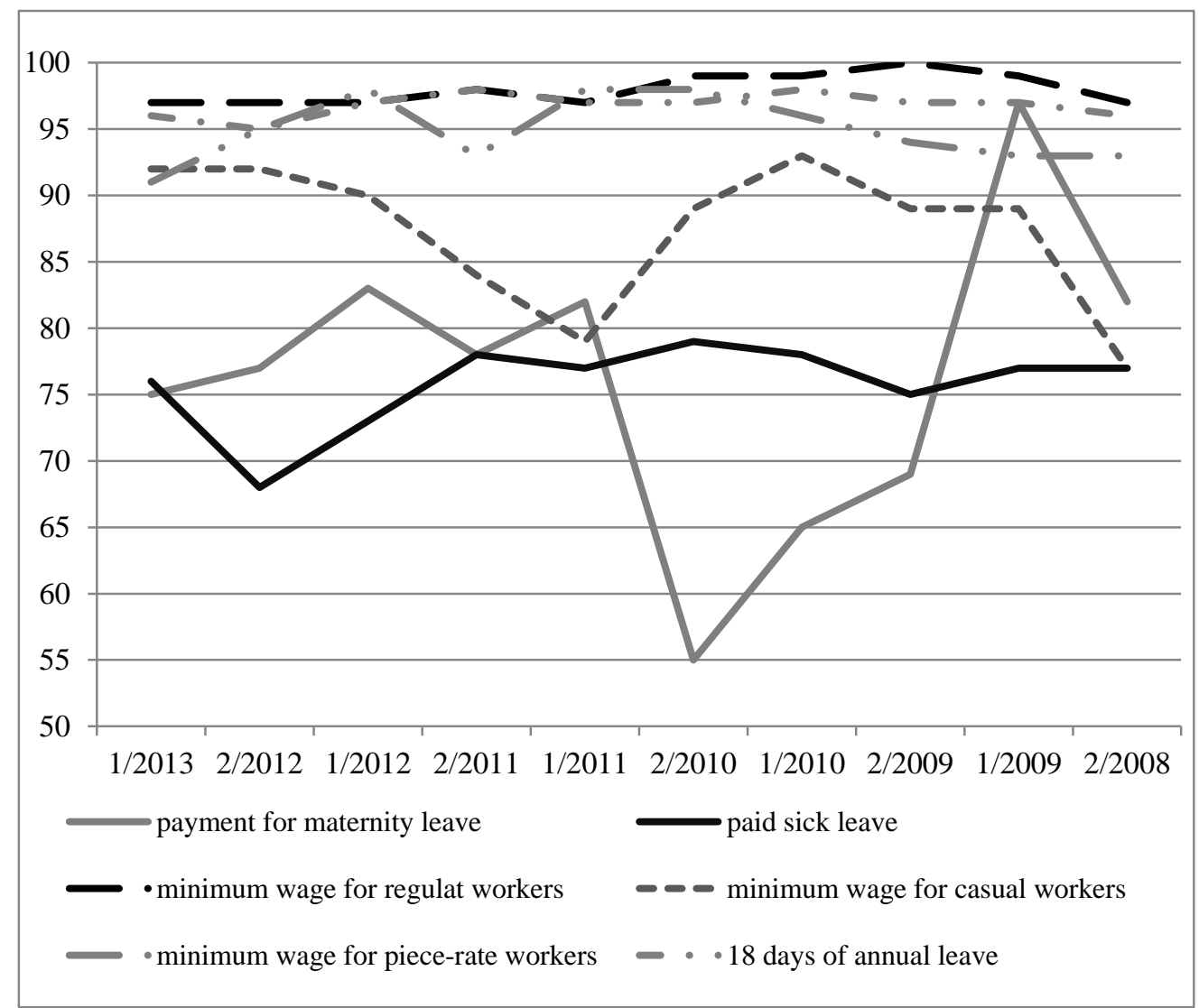

Source: Better Factories (various years). 


\section{Strengths and Weaknesses of the Sector}

As the sector showed strong economic dynamics in the last years and experienced as well institutional and structural changes, specific strengths and weaknesses can be detected. These are in the following explored. Furthermore, this sections aims to shed some light on the potential reasons for the existing shortcomings of the apparel sector in Cambodia.

\section{SWOT Analysis}

In Table 2 below is presented a summary of strengths and weaknesses of the sector according to the current institutional and structural framework of the sector in Cambodia. The strengths of the sector are apparent by the experience of the economy in the apparel sector, as well as the demographic and education settings. The sector still represents high potential growth for an economy with a comparatively low educated labor force and low capital accumulation.

While, the strengths of the sector are mainly economically driven, the major weaknesses are on the legal and social level. Especially, the still existing high level of child labor has to be counted as a major weakness. As presented in the section regarding the specificities of the Cambodian garment industry, social benefits like maternity leaves are already implemented in many companies, similarly to the increasing awareness to create better working conditions. Despite the attempt to improve working conditions, fundamental rights of children are still disobeyed in numerous factories.

Table 2. SWOT Analysis

\begin{tabular}{|l|l|}
\hline $\begin{array}{l}\text { Strengths } \\
\text { - Experience }\end{array}$ & $\begin{array}{l}\text { Weaknesses } \\
\text { - Labor force }\end{array}$ \\
- Child labor \\
Opportunities & Thr-transparent labor contracts \\
$\begin{array}{l}\text { - Textile value chain } \\
\text { - Improvements in working conditions, } \\
\text { might offset low wage level }\end{array}$ & $\begin{array}{l}\text { - Low wage level increases number of } \\
\text { strikes }\end{array}$ \\
\hline
\end{tabular}

Source: Own presentation.

Depending on how the value chain in the apparel sector is transformed in Cambodia in the future, also opportunities for the sector can arise. Currently, most value added comes from direct production, which accounts for only minor value changes in the overall value added curve in the apparel industry (Staritz 2012: Figure 4). All other services, like distribution, marketing, but also design and the purchase of logistics services for raw materials produce a higher added economic value. Therefore, the Cambodian apparel sector could create further economic opportunities by widening the services along the value chain in the garment sector.

These opportunities are also strongly related to the potential threats of the sector. Currently, the major part of factories is foreign owned. According to a study by the World Bank (Staritz 2011: Figure 4.2), 25\% of Cambodian 
garment companies are owned by FDIs from Taiwan, $19 \%$ by FDIs from Hong Kong, and $18 \%$ by FDIs from China. Only a minority of $7 \%$ of garment companies are Cambodian-owned. This dependence on these economies and other economic actors (e.g. companies, investors and institutions) pose the threat that main elements of the value chain of garment production can in the future be transferred to other economies. Additional threats can be detected related to wage levels, which are too low, resulting in strikes and hampering social peace. Therefore a further increase in the minimum wage level could serve as a tool to minimize this threat.

Figure 4. Child Labor and Labor Rights Discrimination 2008-2013

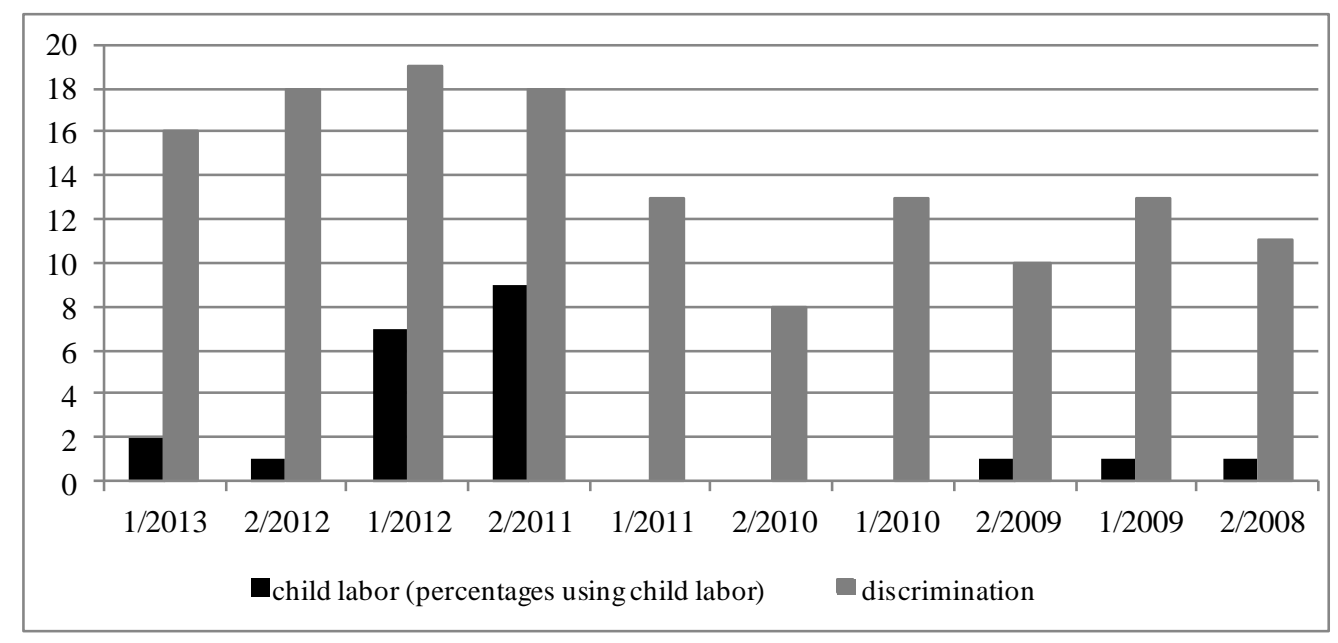

Source: Better Factories (various years).

\section{Analysis of Reasons for Shortcomings in Cambodia}

One of the major shortcomings in the labor structure in Cambodia's garment industry is the still high percentage of child labor. Figure 4 shows the estimates of child labor according to a survey by the project Better Factories. Despite the fact that the percentage of companies varies significantly in 6months periods, the percentage of child labor has even increased in the last years. While $9 \%$ of companies admitted to using child labor in 2011, only $1 \%$ indicated that in 2008/2009. Also, the interviewed representative of a company that monitors labor conditions in the garment industry stated that in 2010 there was virtually no child labor and little forced labor at that time (interview Gridling), underlining the increase in child labor in recent years. Comparing this data with the fact that Cambodia's apparel industry managed to achieve significant increases in growth after the economic downturn due to the global financial crisis, it can be concluded that part of the success of Cambodia's garment industry is built on disobeying fundamental rights. Similarly a significant percentage of factories admit to discriminating labor rights like maternal leave (Figure 4), and as shown in Figure 5, over $40 \%$ of workers have no contract. 
Reasons for these shortcomings might be the strong increase in the number of garment factories over the last years (412 exporting factories in the sector in April 2013 compared to 261 in April 2009 and 313 factories in November 2008, Better Factories: various years) and the ongoing global pressure on the wage level, which had already been comparatively low before the global financial crisis and despite of international pressure, would need a significant rise to create sustainable internal consumer demand.

Figure 5. Contract Duration of Workers Employed at Current Factory for over 2 Years

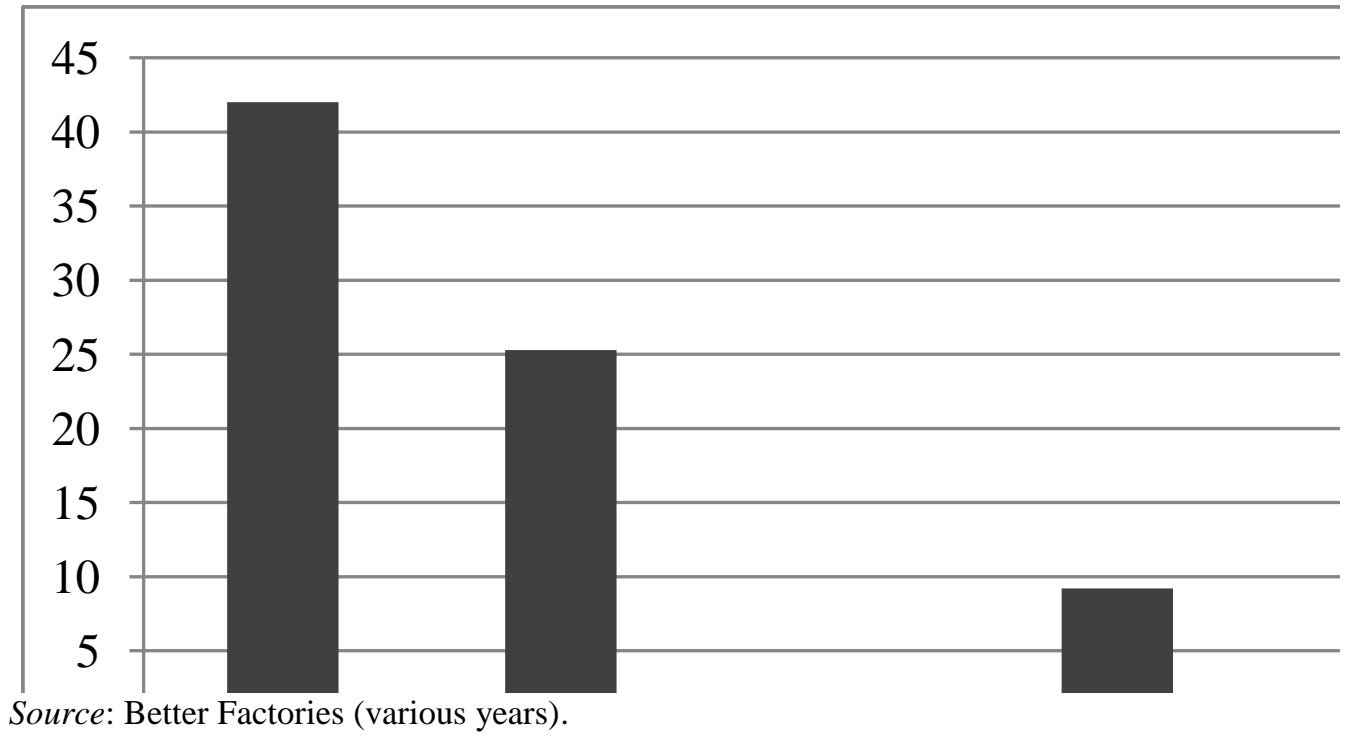

\section{Conclusions and Outlook}

The Bilateral Textile Agreement with the United States had helped improving the working conditions in the Cambodian garment industry. However, as shown in this paper, some aspects of working conditions in this industry have not been maintained. Especially, in recent years part of the companies cut corners in an attempt to reduce labor related costs when aiming to compete with other low-cost producers. This has among others had the effect that increasing numbers of factories are paying below minimum wages for casual workers and are not following regulations regarding the payment of maternity benefits. Child labor has become a lot more widespread in the garment industry in recent years. The worsening of labor conditions is reflected in a significant increase in the number of strikes. While such cost-cutting practices might have short-term benefits for the producers, they threaten to undermine the competitive position of Cambodia as a garment producer in the long term. International clothing brands are under increasing scrutiny and pressure to sell products that are produced under good working conditions. By no longer adhering to standards set under the agreement with the United States, Cambodia is giving up a unique selling position in an industry that can easily 
relocate to other business locations, especially given the fact that the majority of garment producers in Cambodia are foreign owned.

\section{References}

ACTIF - African Cotton and Textile Industries Federation (2010) Report on Cambodia textile \& garment industry. Retrieved from http://goo.gl/dyfpcC. [Accessed: 31 October 2013].

Appelbaum E (1979) The labor market. In Eichner A (ed.). A Guide to Post-Keynesian Economics. New York: M.E. Sharpe. pp. 100-119.

Appelbaum E (1985) Employment and the distribution of earned income. Journal of Post-Keynesian Economics 7(4): 594-602.

Arnold D (2013) "Workers" agency and re-working power relations in Cambodia's garment industry. Working Paper 24 Capturing the Gains 2013. Maastricht University, Netherlands.

Asian Development Bank (2015) Cambodia: Economy. Retrieved from http://goo.gl/dyfpcC. [Accessed: 27 January 2015]

Asuyama Y, Neou S (2012) How has the Cambodian garment industry evolved? In Fukunishi (ed.). Dynamics of the Garment Industry in Low-Income Countries: Experience of Asia and Africa (Interim Report). Chousakenkyu Houkokusho, IDE-JETRO. Retrieved from http://goo.gl/6bOfou. [Accessed: 18 December 2013]

Better Factories (various years) Synthesis report on working condition in Cambodia's garment sector ILO. Retrieved from http://goo.gl/piHPbH. [Accessed: 18 December 2013]

Better Work (2014) Better Factories Cambodia. Retrieved from http://goo.gl/SuRai2. [Accessed: 20 October 2015]

Cambodia Institute of Development Studies (2009) Study on minimum wage in Cambodia's garment industry. Retrieved from http://goo.gl/TcGzLD. [Accessed: 29 January 2015]

Central Intelligence Agency (2013) Economy: Cambodia. Retrieved from https://goo.gl/dkD7R. [Accessed: 26 November 2013]

GMAC - Garment Manufacturers Association of Cambodia (2013) Annual Report. Retrieved from http://goo.gl/Kwx5j4. [Accessed: 21 November 2013]

GMAC - Garment Manufacturers Association of Cambodia (2014) Consolidated data for garment and textile exports. Retrieved from http://goo.gl/EJpLst. [Accessed: 29 January 2015]

International Labor Office (2012) Decent Work, Country Profile Cambodia. Retrieved from http://goo.gl/jNnfXZ. [Accessed: 13 February 2013]

King J (2001) Labor and unemployment. In Holt R, Pressman S (edn.) A New Guide to Post Keynesian Economics. London: Rutledge. pp. 65-78.

Leamer E (1995) The Heckscher-Ohlin Model in Theory and Practise, Princton Studies in International Finance. Department of Economics, Princton University 77. Retrieved from http://goo.gl/ufIvCX. [Accessed: 10 January 2015]

Myrdal G (1973) Asiatisches Drama. Suhrkamp: Frankfurt am Main.

National Institute of Statistics (2010) Labour and social trends in Cambodia 2010. Retrieved from http://goo.gl/moSBr5. [Accessed: 31 October 2013]

Oately T (2010) International Political Economy. New York: Pearson ( $4^{\text {th }}$ edn.), p. 145. 
Öz F (2008) Decent work and wage indicator. Retrieved from http://goo.gl/y8PPTy. [Accessed: 28 November 2013]

Phnom Penh Securities (2012) Cambodian textiles \& garment industry. Special Report. Retrieved from http://goo.gl/9AkcKO. [Accessed: 18 November 2013]

Ravin C, Cheong T (2013) Export-led growth in Cambodia: an empirical study. Discussion Paper 03/13. Department of Economics, Monash University.

Savchenko Y, Acevedo GL (2012) Female Wages in the Apparel Industry Post-MFA. Policy Research Working Paper 6061, World Bank. Retrieved from http://goo.gl/osMmC8. [Accessed: 29 January 2015]

Seccareccia M (1991) An alternative to labour-market orthodoxy: the postKeynesian/institutional policy view. Review of Political Economy 3.1: 43-61.

Source ASEAN (2010) Cambodia textile and garment industry. Retrieved from http://goo.gl/6jpBdX. [Accessed: 15 November 2013]

Staritz C (2012) Apparel exports-still a path for industrial development? Dynamics in apparel global value chains and implications for low-income countries. Working Paper, ÖFSE 34: 4.

Staritz C (2011) Making the Cut? Low income countries and the global clothing value chiain in a post-quota and post-crisis world. Washington: World Bank. Retrieved from http://goo.gl/Je2Uh. [Accessed: 01 November 2013]

Wells D (2006) "Best practice" in the regulations of international labor standards: lessons of the US-Cambodia textile agreement. Comparative Labor Law \& Policy Journal 27(3): 357

World Economic Forum (2013). Retrieved fromhttp://goo.gl/HdlfvG. [Accessed: 26 November 2013]

WTO - World Trade Organization (2013) Merchandise trade. Retrieved from http://goo.gl/9rwCbA. [Accessed: 26 November 2013]

\section{Interview}

Personal Interview (2010) Gridling, Max, Cosmos Services, Phnom Penh. 